\title{
GESTIÓN ACTIVA DE PORTAFOLIOS MEDIANTE LA APLICACIÓN DEL MODELO DE TREYNOR - BLACK
}

\section{Alejandro Vargas Sánchez}

\section{RESUMEN}

En el presente documento se expone la teoría de gestión activa de portafolios a través de la aplicación del modelo de Treynor Black. El objetivo principal es mostrar el impacto positivo que una gestión activa de portafolios puede tener en términos de rendimiento y riesgo, permitiendo de esta manera desplazar positivamente la función de utilidad de un inversionista adverso al riesgo; estos beneficios se pueden alcanzar a partir de la incorporación de títulos valores con rendimientos anormales cuyos precios de mercado son diferentes a sus valores de equilibrio. Los resultados alcanzados permiten corroborar esta situación, aunque también se pone de manifiesto que cuando los rendimientos anormales son muy elevados, puede dar como consecuencia que el portafolio de activos riesgosos se concentre excesivamente en aquellos títulos con rendimientos anormales generando mayor exposición a los riesgos no sistemáticos.

Palabras Clave: Gestión Activa de Portafolios, Modelo de Treynor Black, Rendimientos anormales, Función de Utilidad, Rendimiento y Riesgo. 